Lesser Sunda

P-ISSN: 2775-0078

Januari 2021

E-ISSN: 2775-0086

Vol. 1(4):24-28

\title{
Kondisi Terumbu Karang di Perairan Gili Gede, Sekotong Lombok Barat
}

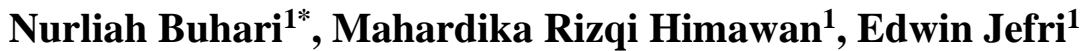 \\ ${ }^{1}$ Program Studi Ilmu Kelautan, Jurusan Perikanan dan Ilmu Kelautan, \\ Fakultas Pertanian, Universitas Mataram \\ *nurliah.buhari@unram.ac,id
}

Naskah diterima : 12 Desember 2020, Disetujui : 14 Januari 2021

\begin{abstract}
Protection and sustainable data collection are very important in order to protect the coral reef ecosystem. This research was conducted to monitor and determine the condition of coral reefs in the eastern part of Gili Gede Island, which is administratively located in Sekotong Sub-District, West Lombok Regency, NTB. The method used is Line Intercept Transect (LIT). Furthermore, the starting point of the transect stretch is recorded using GPS coordinates and the depth gauge is used to estimate the depth of the water. The results showed that the status of coral reefs tended to be badly damaged with the mean value of all stations (21.92\%). Fishery activities and pressure from the land are thought to be several factors that tend to affect the poor coastal ecosystem.
\end{abstract}

Keywords : Coral reefs, gede island, sekotong

\section{PENDAHULUAN}

Pemantauan (monitoring) adalah pengamatan yang dilakukan terhadap suatu sistem sehingga dapat menggambarkan dan mendeteksi perubahan kondisi terhadap sistem tersebut, misalnya ekosistem pesisir (McKenzie dan Campbell, 2002). Pemantauan kesehatan ekosistem pesisir, seperti terumbu karang penting dilakukan untuk mengetahui pengaruh dari perubahan alam maupun keberadaan aktifitas manusia. Kesehatan terumbu karang dapat diukur melalui penilaian terhadap struktur bentik suatu dasar perairan yang penting dilakukan karena terkait dengan ketersediaan stok ikan. Keanekaragaman hayati ikan karang di Indonesia diketahui sangat tinggi. Tercatat sebanyak 2.200 spesies ikan menempati perairan ini (Giyanto et al., 2014). Upaya perlindungan dan pendataannya yang berkelanjutan menjadi sangat penting dalam rangka menjaga ekosistem terkait seperti lamun dan terumbu karang.

Penelitian ini dilakukan untuk memantau dan mengetahui kondisi ekosistem pesisir berupa terumbu karang di Pulau Gili Gede bagian Timur, yang secara administrasi berada di Kecamatan Sekotong, Kabupaten Lombok Barat, NTB. Hasil dari penelitian ini diharapkan dapat menyediakan kebutuhan data terhadap pengelolaan Pulau Gili Gede. Sehingga, kebijakan dan strategi konservasi dapat direncanakan dan diimplementasikan dengan baik. 


\section{METODE PENELITIAN}

Penelitian dilakukan di 3 stasiun yang terletak di Timur Pulau Gili Gede, Kecamatan Sekotong, Kabupaten Lombok Barat, NTB (Gambar 1, Tabel 1).

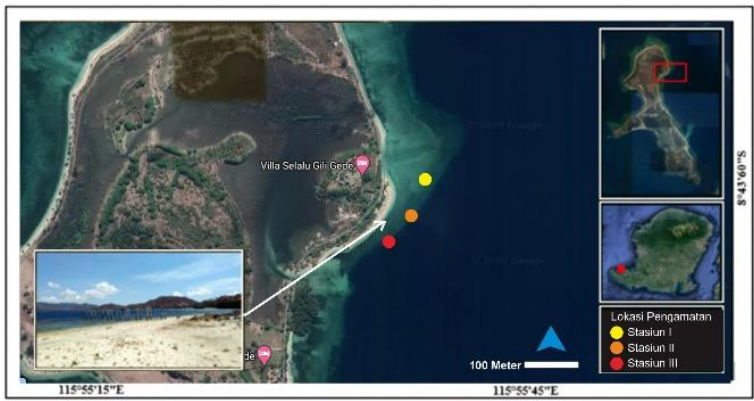

Gambar 1 Lokasi Stasiun penelitian terumbu karang di bagian timur Pulau Gili Gede, Lombok Barat

Tabel 1 Koordinat posisi pada setiap stasiun penelitian

\begin{tabular}{ll}
\hline Kode & Koordinat \\
\hline \multirow{2}{*}{ Stasiun 1 } & $8^{\circ} 44^{\prime} 03.1 " \mathrm{LS}$ \\
& $115^{\circ} 55^{\prime} 38.5^{\prime \prime} \mathrm{BT}$ \\
\hline Stasiun 2 & $8^{\circ} 44^{\prime} 27.1^{\prime \prime L S}$ \\
& $115^{\circ} 55^{\prime} 33.0^{\prime \prime B T}$ \\
\hline \multirow{2}{*}{ Stasiun 3 } & $8^{\circ} 44^{\prime} 26.8^{\prime \prime} \mathrm{LS}$ \\
& $115^{\circ} 55^{\prime} 32.9^{\prime \prime} \mathrm{BT}$ \\
\hline
\end{tabular}

\section{Pengamatan Terumbu Karang}

Metode Line Intercept Transect (LIT) (English et al., 1994) dengan menyelam
Metode Line Intercept Transect (LIT) (English et al., 1994) dengan menyelam bawah air digunakan dengan membentangkan roll meter pada dasar perairan sepanjang $50 \mathrm{~m}(5.000 \mathrm{~cm})$ sejajar garis pantai pada kedalaman 5-7 meter. Selanjutnya, titik awal bentangan transek dicatat koordinatnya menggunakan GPS dan Depth gauge digunakan untuk estimasi kedalaman perairan. Jenis-jenis substrat penyusun dasar perairan yang bersinggungan dengan bentangan transek kemudian diidentifikasi dan dilakukan pencatatan, termasuk panjang singgungannya pada lembar data yang kedap air. Jenis/kategori substrat dasar perairan mengacu pada English et al. (1997) (Tabel 2).

bawah air digunakan dengan membentangkan roll meter pada dasar perairan sepanjang $50 \mathrm{~m}(5.000 \mathrm{~cm})$ sejajar garis pantai pada kedalaman 5-7 meter. Selanjutnya, titik awal bentangan transek dicatat koordinatnya menggunakan GPS dan Depth gauge digunakan untuk estimasi kedalaman perairan. Jenis-jenis substrat penyusun dasar perairan yang bersinggungan dengan bentangan transek kemudian diidentifikasi dan dilakukan pencatatan, termasuk panjang singgungannya pada lembar data yang kedap air. Jenis/kategori substrat dasar perairan mengacu pada English et al. (1997) (Tabel 2). 
Tabel 2 Jenis/kategori substrat dasar perairan English et al. (1997)

\begin{tabular}{|c|c|c|c|}
\hline \multicolumn{2}{|l|}{ Jenis/Kategori } & Kode & Keterangan \\
\hline \multicolumn{2}{|l|}{ Dead Coral } & DC & Karang yang baru mati, berwarna putih \\
\hline \multicolumn{2}{|c|}{ Dead Coral with Algae } & DCA & Karang mati yang ditumbuhi alga \\
\hline \multicolumn{4}{|l|}{ Hard Coral: } \\
\hline \multirow[t]{5}{*}{ Acropora } & Branching & ACB & Bercabang seperti ranting. \\
\hline & Encrusting & $\mathbf{A C E}$ & $\begin{array}{l}\text { Bentuk merayap, seperti Acropora yang } \\
\text { belum sempurna. }\end{array}$ \\
\hline & Submassive & ACS & Bercabang lempeng dan kokoh. \\
\hline & Digitate & ACD & Percabangan rapat seperti jari tangan. \\
\hline & Tabulate & ACT & Percabangan arah mendatar. \\
\hline \multirow[t]{8}{*}{ Non Acropora } & Branching & CB & Bercabang seperti ranting pohon. \\
\hline & Encrusting & $\mathbf{C E}$ & Bentuk merayap, menempel pada substrat. \\
\hline & Foliose & CF & Bentuk menyerupai lembaran. \\
\hline & Massive & CM & Bentuk seperti batu besar. \\
\hline & Submassive & CS & Bentuk kokoh dengan tonjolan. \\
\hline & Mushroom & CMR & Bentuk seperti jamur, soliter. \\
\hline & Millepora & CME & $\begin{array}{l}\text { Semua jenis karang api, warna kuning } \\
\text { diujung koloni. }\end{array}$ \\
\hline & Heliopora & CHL & $\begin{array}{l}\text { Karang biru, adanya warna biru pada } \\
\text { skeleton. }\end{array}$ \\
\hline \multicolumn{4}{|l|}{ Other Fauna: } \\
\hline Soft Coral & & SC & Karang dengan tubuh lunak \\
\hline Sponge & & SP & Contoh: Aaptos aaptos \\
\hline Zoanthids & & $\mathbf{Z O}$ & Contoh: Palythoa tuberculosa \\
\hline Others: & & OT & Anemon, teripang, gorgonian, kima \\
\hline \multirow{5}{*}{ Algae } & Algae Assemblage & $\mathbf{A A}$ & Terdiri lebih dari satu jenis alga \\
\hline & Coralline Algae & CA & Alga yang mempunyai struktur kapur \\
\hline & Halimeda & HA & Alga dari genus Halimeda \\
\hline & Macroalgae & MA & Alga berukuran besar \\
\hline & Turf Algae & TA & Menyerupai rumput-rumput halus \\
\hline \multirow[t]{5}{*}{ Abiotic } & Sand & $\mathbf{S}$ & Pasir \\
\hline & Rubble & $\mathbf{R}$ & Patahan karang yang berserakan \\
\hline & Silt & SI & Lumpur \\
\hline & Water & WA & $\begin{array}{l}\text { Kolom air /celah dengan kedalaman lebih } \\
\text { dari } 50 \mathrm{~cm}\end{array}$ \\
\hline & Rock & RCK & Tapakan karang termasuk batu kapur \\
\hline Other & & DDD & Data tidak tercatat atau hilang \\
\hline
\end{tabular}

\section{Analisis Data}

Analisa data terumbu karang dilakukan untuk mendapatkan persen penutupan setiap jenis substrat dasar perairan yang bersinggungan dengan transek. Persentase penutupan dihitung menggunakan rumus sederhana sebagai berikut (English et al., 1994):

$$
\mathbf{L}_{\mathbf{i}}=\mathrm{N}_{\mathrm{i}} / \mathbf{L} \times \mathbf{1 0 0 \%}
$$

Keterangan:

$\mathrm{L}_{\mathbf{i}}=$ Persentase penutupan jenis $\mathrm{i}$ 
$\mathrm{N}_{\mathrm{i}}=$ panjang total $(\mathrm{Cm})$ penutupan jenis i

$\mathrm{L}=$ Panjang total transek

\section{HASIL DAN PEMBAHASAN}

Jenis penutup dasar permukaan di perairan Stasiun 1 (Gambar 2) didominasi oleh substrat berupa rubble atau pecahan karang keras (35.04\%), diikuti makro alga dan spons (21.72\%) karang mati yang diselimuti alga (19.24\%) dan pasir (10.16\%). Persentase penutupan karang keras hidup adalah $13.84 \%$ atau sepanjang 692 centimeter dari 5.000 centimeter panjang transek. Karang keras terdiri dari karang dengan bentuk pertumbuhan acropora coral branching (ACB), coral branching (CB), coral encrusting (CE), coral foliose (CF), coral massive (CM), coral sub massive (CSM) dan coral mushroom (CMR) (Gambar 2).

Jenis penutup dasar perairan pada Stasiun 2 dan 3 didominasi oleh patahan karang yang berserakan (rubble $\mathbb{R})$ dan makro alga (MA) (Gambar 2). Pada Stasiun 1, dominasi patahan karang yaitu sebesar $54,26 \%$ (Gambar 2). Persentase jenis tutupan karang keras hidup adalah sebesar 32,62\%, dengan komposisi Coral Massive (CM)
18,38\%, Acropora coral tabulate (ACT) 6,06\%, Coral submassive (CSM) 4,22\%, Acropora coral branching (ACB) 1,72\%, Coral branching (CB) $1,16 \%$, Coral encrusting (CE) 0,66\% dan Coral Mushroom (CMR) 0,42\%. Karang mati ditumbuhi alga (DCA) memiliki persen penutupan $12,10 \%$ dan diikuti pasir sebesar $1,02 \%$.

Patahan karang dan makro alga jenis Padina sp. mendominasi Stasiun 2 dengan persentase sebsesar 61,32\% (Gambar 2). Selain itu, patahan karang memiliki persen penutupan $14,40 \%$. Persentase jenis tutupan karang keras hidup adalah sebesar 18,60\%, dengan komposisi Coral branching (CB) 6,68\%, Acropora coral branching (ACB) 5,86\%, Coral Massive (CM) 3,60\%, Coral submassive (CSM) 1,32\%, Coral Mushroom (CMR) 0,76\% dan Coral encrusting (CE) $0,38 \%$. Pada jenis tutupan lain, pasir (S) memiliki persen penutupan sebesar 2,78\% sedangkan karang mati ditumbuhi alga (DCA) dan sponge (SP) masing-masing adalah sebesar $1,68 \%$ dan $1,22 \%$. Gambar 2 menunjukkan beberapa jenis tutupan dasar perairan yang bersinggungan dengan transek pada tiap stasiun pengamatan. 


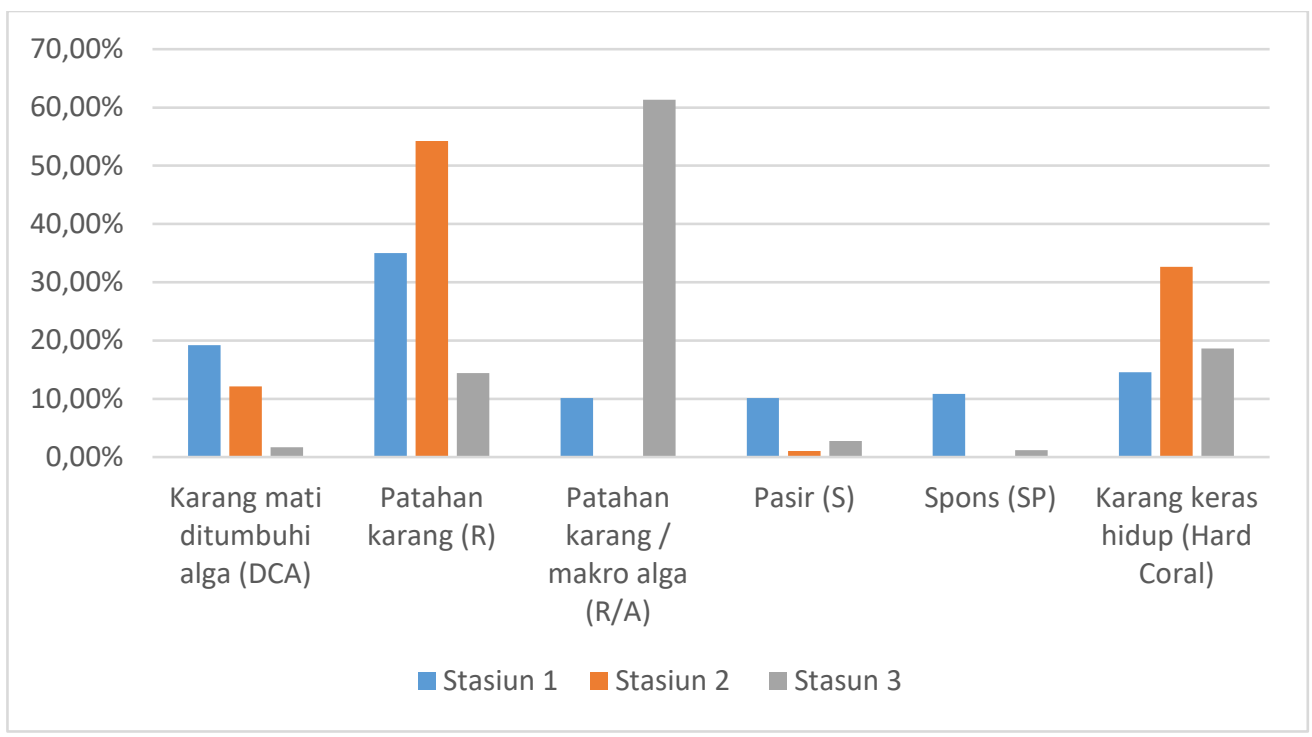

Gambar 2 Persentase jenis penutup dasar perairan pada Stasiun 1,2 dan 3

Kepmen LH nomor 04/ 2001 mendeskripsikan status terumbu karang berdasarkan tutupan karang hidup sebagai berikut; 0-24,9\% rusak buruk, 25-49,9\% rusak sedang, $50-74,9 \%$ baik baik dan $>75 \%$ baik baik sekali. Mengacu pada nilai tersebut, status pada Stasiun 1 adalah rusak buruk, Stasiun 2 rusak sedang dan Stasiun 3 adalah rusak buruk. Nilai rata-rata dari ketiga stasiun tersebut $(21,92 \%)$ menunjukkan bahwa terumbu karang di perairan bagian timur Pulau Gili Gede, Lombok Timur dalam status rusak buruk.

\section{KESIMPULAN}

Penilaian dan status ekosistem pesisir bagian Timur Pulau Gili Gede menunjukkan bahwa status terumbu karang cenderung rusak buruk dengan nilai rata-rata dari ketiga stasiun (21,92\%). Aktivitas perikanan dan tekanan tekanan dari daratan diduga menjadi beberapa faktor yang memengaruhi cenderung kurang baiknya ekosistem pesisir tersebut.

\section{DAFTAR PUSTAKA}

English, S., Wilkinson C., Baker V. 1994. Line intercept transect. In: English S., Wilkinson C., Baker V. (eds) Survey manual for tropical marine resources. Australian Institute of Marine Science:Townsville.

Giyanto, A.E.W. Manuputty, M. Abrar, R. M Siringoringo, S.R. Suharti, K. Wibowo, I.N. Edrus, U.Y. Arbi, H.A.W. Cappenberg, H.F.S.Y.Tuti, D.Z. Anita. 2014. Panduan Monitoring Kesehatan Terumbu Karang/editor: Suharsono, Ono Kurnaen Sumadhiharga. COREMAP CTI LIPI: Jakarta.

Keputusan Menteri Negara Lingkungan Hidup Nomor 02 Tahun 2001 tentang Kriteria Baku Kerusakan Terumbu Karang.

McKenzie, L.J., Campbell S.J. 2002. Seagrass-Watch: Manual for Community (citizen) Monitoring of Seagrass Habitat. Western Pacific Edition: QFS, NFC, Cairns 